\title{
Muddling Through the European Bloc System: The Evolution of Italian-Polish Relations over the 1970's and 1980's
}

\author{
Sara TAVANI
}

\begin{abstract}
This article discusses the role Italian Ostpolitik played in normalising Warsaw's postwar relations with Western Europe, as well as in encouraging a greater Polish confidence in the EC/EU security prospects. All of which anticipated Poland's democratic transition and eventual access to the European Union. The intensifying Italian-Polish dialogue and economic cooperation over the 1970's and 1980's, both encouraged Poland's reform process and assuaged its wariness regarding changes in the continental status-quo. These bilateral dynamics are investigated against the backdrop of an awakening vision of the European Union, envisioned to become independent from the bloc system and based upon mutual interdependence.

Keywords: Italian Ostpolitik, Polish Westpolitik, European Détente, European security, Interdependence
\end{abstract}

\section{Introduction}

This paper will discuss the role played by Italian Ostpolitik in normalising Poland's post-war relations with Western Europe, as well as in encouraging a greater Polish confidence in the EC/EU security prospects, all of which anticipated Poland's democratic transition and eventual access to the European Union. During the 1970's and 1980's, Poland faced continuous and significant changes on both its domestic as well as international stages. In fact, Polish economic and social reforms, launched under Edward Gierek at the beginning of the 1970's, became more articulated over the following years and went hand in hand with the transformation of EastWest relations in Europe. ${ }^{1}$ This meant an evolutionary and varied perception of the European building process on the part of Poland, since both the subject and the object of this perception were changing. Poland was, indeed, experiencing the economic and social consequences of its domestic reforms, as well as its overtures towards the West, especially towards Western Europe. At the same time, the nature itself of political cooperation in Europe was starting to develop, both between Eastern and Western countries and among the EC members themselves, with the introduction

1 Works on this subject include Wilfried Loth, George H. Soutou (eds.), The Making of Détente: Eastern and Western Europe in the Cold War, 1965-75, London-New York: Routledge, 2008; Piers N. Ludlow (ed.), European Integration and the Cold War: OstpolitikWestpolitik, 1965-1973, London: Routledge, 2007; John Van Oudenaren, Détente in Europe. The Soviet Union and the West since 1953, Duhram: Duke University Press, 1991. 
of the EPC (European Political Cooperation) and the emergence of the European Union project. ${ }^{2}$

Italian diplomatic records from the Giulio Andreotti Archive ${ }^{3}$ shed light on the evolution of the Italian-Polish relations over these years and provide insight on how Poland weighed the transformations that were sweeping across the continent as well as the role that the country could play in this changing Europe. The resulting image is of a lingering wavering between attraction and mistrust towards the European Community as well as the European Union project. On one hand, the Polish government, and the Polish society as well, took great interest in a unified and independent Europe that was gaining popularity in the early 1970's. In fact, this ideal Europe envisioned becoming a geo-strategic pole independent from the superpowers, rescued from the bloc system of balance, and prosperous, thanks to expanded social and economic ties. In this new Europe, Poland would have been able to rediscover its historical roots without security concerns that included territorial revisionism, as well as its political and economic subordination. On the other hand, the Polish government often exhibited wariness towards this ambitious plan, which the West European countries were carrying out between ups and downs. The attraction was therefore hampered by a lack of confidence in the European ability to scrap national interests and discords in order to build a reliable security framework. The rapprochement to Western Europe also jeopardized Polish relations with its Eastern allies, especially the Soviet Union and the German Democratic Republic. This was to be avoided, since the security ties with the Warsaw Pact remained irreplaceable as long as the security of the continent lied upon the military blocs.

Italian-Polish relations during the 1970's and 1980 have clearly mirrored Poland's hesitations, especially after the crisis of détente had plunged confidence levels between the East and West. In fact, Poland's dual perception of the European Community corresponded to the Italian diplomatic efforts that included encouraging Polish European vocation while, at the same time, assuaging its security and economic concerns, by way of reasserting European Union credibility. This was especially true in early 1980 's, when Polish uncertainties became greater and thereby badly soured the sensitive course of German-Polish relations, following the INF (Intermediate Nuclear Forces) deployment on German soil and the election of the CDU-FDP coalition. Italian diplomatic initiatives,

2 Cf. among others Angela Romano, "The main task of European Political Cooperation: fostering détente in Europe", in Poul Villaume, Odd A. Westad (eds.), Perforating the Iron Curtain: European Détente, Transatlantic Relations, and the Cold War, 1965-1985, Copenhagen: Museum Tusculanum Press, 2010, pp. 123-142; Daniel Möckli, European Foreign Policy during the Cold War, London: I. B. Tauris, 2009, pp. 95-139.

3 Giulio Andreotti Archive (GA) is currently part of the Historical Archive of the Luigi Sturzo Institute (ASILS), Rome. 
such as the 1984 visit to Warsaw by Foreign Minister Giulio Andreotti, filled the vacuum deriving from Chancellor Kohl's diplomatic troubles in Central Europe as well as President Mitterrand's difficulties in conciliating French Ostpolitik with his human rights policy. At the same time, Italian diplomatic activity was also directed towards its European allies with the aim of re-launching political as well as military integration, so to make the European project more attractive; the 1983 Stuttgard Resolution, based upon the Colombo-Genscher Plan, and the 1984 WEO (Western European Organization) update were intended to inspire greater credibility. ${ }^{4}$

These diplomatic initiatives succeeded in reintegrating Poland into a normalized circuit of East-West relations as well as fostering a more active role, on the part of Warsaw, in the European pursuit of concrete confidence-building and disarmament measures at the Stockholm Conference. These efforts ultimately persuaded the Polish government to accelerate its reform process and accept the dismantlement of the bloc system. Gorbačev's reforms and the NATO Eastern enlargement, which implied a stretching of the US strategic guarantee to Poland, certainly had a fundamental role in this process. Nonetheless, this bipolar evolution could not be more than a strategic frame of both a peaceful inter-European coexistence and a final settlement of the post-war inheritance.

\section{The intensifying Italian-Polish cooperation following the normalisation of Polish-West German relations}

Poland's attraction to Western Europe was greatly boosted by the 1972 ratification of the Treaty between Warsaw and Bonn. In fact, the treaty formally provided for Bonn's acknowledgement of the Oder-Neisse post-war border ${ }^{5}$ and it represented the first breach in the Iron Triangle policy, which had traditionally committed Poland, East Germany and Czechoslovakia to a firm policy of closure towards the West. $^{6}$

4 Recent works on the Italian role in the EC/EU integration process include Antonio Varsori, L'Italia e la fine della guerra fredda: La politica estera dei governi Andreotti (1989-1992), Bologna: Il Mulino, 2013, and La Cenerentola d'Europa. L'Italia e l'integrazione europea dal 1947 ad oggi, Soveria Mannelli: Rubbettino, 2010; Piero Craveri, Antonio Varsori (eds.), L'Italia nella costruzione europea. Un bilancio storico (1957-2007), Milano: Franco Angeli, 2009; Luciano Tosi (ed.), L'Italia e la dimensione sociale nell'integrazione europea, Padova: Cedam, 2008.

5 See Wanda Jarząbek, "Polish reactions to the West German Ostpolitik and East-West détente, 1966-1978", in Perforating the Iron Curtain,cited above, pp. 35-56, and Krzysztof Ruchniewicz, "Ostpolitik and Poland", in Carole Fink, Bernd Schaefer (eds.), Ostpolitik, 1969-1974: European and Global Responses, Cambridge: Cambridge University Press, 2009, pp. 39-57.

6 Cf. Pierre-Frédéric Weber, Le Triangle RFA-RDA-Pologne (1961-1975). Guerre froide et normalisation des rapports germano-polonais, Paris: L'Harmattan, 2007, pp. 51-168. See 
Willy Brandt's Ostpolitik was not able to alleviate all of the Polish concerns regarding the Oder-Neisse border, especially due to the perception that it was not fully accepted by several German political and public circles, such as the Exiles' Association. ${ }^{7}$ Despite this, as the US State Department had predicted ${ }^{8}$, the Warsaw treaty brought about a general improvement in German-Polish as well as European East-West relations by curbing the satellites' political reliance on Moscow, consequently increasing Soviet bloc fragility along with East German isolation. Moreover, the treaty went hand in hand with a collective call for pan-European negotiations aimed at reshaping the continental security system and reinforcing East-West cooperation. ${ }^{9}$ These calls partially derived from and fulfilled the Polish quest for a commonagreement on Central Europe which the Warsaw government had started to envisage in 1957 with the so-called Rapacki or Gomutka Plan. ${ }^{10}$ In this new climate of confidence-building, Poland began to develop its Westpolitik, by establishing a wider range of closer diplomatic, commercial and cultural relations with Western Europe. Gierek actively promoted several political improvements in Polish Western relations, which included greater freedom of movement and a more flexible policy on family reunions. ${ }^{11}$ This rapprochement fostered Polish commercial relations with the EC members and with the EC itself by driving Western investments and credits in Poland, thus giving rise to the prosperous, but short-lived, Polish Market Socialism. ${ }^{12}$

also Willy Brandt, Memorie [Erinnerungen], Milano: Garzanti, 1991, pp. 196-238.

7 See Jurij V. Posadnev, Problema zapadnoj granicy PNR v Bundestage FRG v 1969-1972 g, Moskva: Ministerstvo Prosveščenija RSFSR, 1983.

8 "Possible FRG Non-Aggression Pact with Poland", US Department of State background paper, 12.15.1965, Thomson Gale Collection (DDRS), n. 3526, v. 1992.

9 This process was defined by Oliver Bange as "the multilateralisation of Ostpolitik" in "An Intricate Web: Ostpolitik, the European Security System and German Unification", in Oliver Bange, Gottfried Niedhart (eds.), Helsinki 1975 and the Transformation of Europe, Oxford-New York: Berghahn Books, 2008, p. 24. See also Andrej V. Zagorskij, Chel'sinkskij process, Moskva: Prava Čeloveka, 2005.

10 Zoltán Marusza, Denuclearization in Central Europe? The Rapacki Plan during the Cold War, 2008 [coldwar.hu/html/en/publications/Online\%20PublicationMar.pdf], last consulted on 07.10.2013.

11 See Julia von Dannenberg, The Foundations of Ostpolitik: The Making of the Moscow Treaty between West Germany and the USSR, London-New York: Oxford University Press, 2008; Arne Hofmann, The Emergence of Détente in Europe. Brandt, Kennedy and the Formation of Ostpolitik, London-New York: Routledge, 2007; Helga Haftendorn, Coming of Age: German Foreign Policy since 1945, Lanham: Rowman \& Littlefield, 2006.

12 Trade with the West reached $50 \%$ of Polish foreign trade and the productivity rate rose from $4.9 \%$ in 1971 to $8.4 \%$ in 1973 . George Andersen, Combat, 16.04.1974. See also COMECON DATA 1979, London: Vienna Institute for Comparative Economic Studies, 1980; Eurostat data reported by Peter Van Ham, The EC, Eastern Europe and European Unity. Discord, Collaboration and Integration since 1947, London-New York: Pinter, 1995. 
Polish Westpolitik, in 1974, led to the Ten-year Agreement between Rome and Warsaw for the development of economic, industrial and technological cooperation. This agreement was required to regulate the growing bilateral commercial and financial exchanges. It also provided for comprehensive cooperation in the economic field, by establishing a Joint Commission of Polish and Italian economic experts in order to translate general provisions into concrete measures. In 1975, the economic Long-term Plan and the Five-year Agreement on economic cooperation completed the terms of the Ten-Year Agreement.

The mid 1970's was therefore the golden period of bilateral cooperation, being that the Italian trade balance was still positive and Polish productivity was still robust. ${ }^{13}$ Exports of Italian goods and machineries, mainly granted by Italian credits, were offset by Polish exports in the energy field, especially coal. This economic synergy was further reinvigorated in October 1977, with Gierek's visit to Rome to sign Italian-Polish protocols on bilateral cooperation. This included the so-called Gierek economic package which provided for new institutional as well as industrial arrangements. According to these agreements, bilateral cooperation had to be enhanced through more intense SME (Small Medium Enterprises) activity, as well as greater exchange diversification.

The protocols also established new bilateral bodies, including a permanent economic committee and working groups within the Joint Commission. Albeit, the Rome Summit in 1977 was also characterized by a dash of pessimism. In fact, Gierek expressed initial concerns regarding Poland's growing dependence on Western credits as well as perplexities regarding outstanding debts and stagnant exports. In response to this, the Polish delegation called for the institution of joint ventures, which aimed to share market risks and improve Polish marketing and export activities. ${ }^{14}$

During his talks in Rome, Gierek also let it be known that Poland feared an escalation in military confrontation within Central Europe, for the most part due to the NATO plans to supply the Federal Republic with neutron bombs, and it was interested in searching for a common ground on security matters. Indeed, Gierek argued that weaknesses in military détente were obstructing political détente and, thus, he held that the SALT agreement between Washington and Moscow was essential to safeguard it. Moreover, prior to arriving in Rome, Gierek had met with Chancellor Schmidt and both leaders had accepted that progress on bipolar disarmament necessitated a more active role on behalf of the medium powers.

13 Cf. Domenico M. Nuti, “The Polish crisis: economic factors and constraints", in Socialist Register, vol. 18, 1981 [socialistregister.com/index.php/srv/article/view/5463], last consulted on 07.10.2013.

14 "Cooperazione economica e industriale italo-polacca", Italian Ministry of Foreign Affairs (IMFA) preparatory study in view of Edward Gierek's visit to Rome, 17-19.10.1977. GA, ASILS, Polonia, Personalità A-K, Gierek, f. 572. 
Therefore, this opened the way for Poland, West Germany and Italy to play direct roles in promoting general disarmament. ${ }^{15}$

In 1977, Gierek was therefore showing signs of uncertainty regarding the solidity of his economic policy as well as fret regarding the Atlantic military plans. Yet, in spite of the emerging concerns, Poland's approach to its Western neighbours was still collaborative and greatly differed from the Soviet approach which was becoming more wary and defensive. ${ }^{16}$ Therefore, the Western countries, including Italy, were strongly keen on maintaining this state of affairs, even if this meant to invest huge amounts in the ever more tottering Polish economy.

Several Italian industries, including FIAT, FINSIDER, the ENI Group, Montedison as well as numerous SME, were involved in Italian-Polish trade, with the car industry having the leading role. This bilateral cooperation was financed by 1975 credits from Mediobanca, for about $\$ 300$ million, and from IMI, for about $\$ 200$ million. ${ }^{17}$ Moreover, Warsaw obtained further large financial concessions in 1977. The Italian Minister of Foreign Trade Rinaldo Ossola visited Poland in June offering new credits for the enlargement of the FIAT-POLMOT joint ventures as well as the FINSIDER project for realizing a coal pipeline between Katowice and Trieste $^{18}$. In October, Gierek bargained in Rome for new credit lines, including \$ 300 million for the steel industry, \$ 100 million for the textile and chemical sectors, and $\$ 75$ million for the engineering industry. ${ }^{19}$

The Italian government also invested greatly in cultural and social exchanges, which included joint cultural events, fellowships, and visiting professorships. To this regard, in 1977, Italian diplomats registered with satisfaction that bilateral cooperation in these fields was "very good" and this led the Italian Ministry to record that "Poland looks on Italy as one of its strong links with the European world and culture", ${ }^{20}$

An even greater impetus was observed in scientific and technological cooperation, which gave evidence of Poland's desire to overcome its technological gap. Moreover, Italian-Polish relations also benefited from the ongoing normalisation

\section{Ibid.}

16 Cf. Georges Sokoloff, The economy of Détente. The Soviet Union and Western Capital, Hamburg-New York: Berg-Leamington Spa, 1987, pp. 177-179.

17 "Interscambio commerciale italo-polacco", Italian Ministry of Foreign Affairs (IMFA) preparatory study in view of Edward Gierek's visit to Rome, 17-19.10.1977, GA, ASILS, Polonia, Personalità A-K, Gierek, f. 572.

18 Minister of Foreign Trade Rinaldo Ossola to Prime Minister Giulio Andreotti, Rome, 8.6.1977, GA, ASILS, Polonia, Personalità A-K, Gierek, f. 572.; "Cooperazione economica e industriale italo-polacca", Italian Ministry of Foreign Affairs (IMFA) preparatory study in view of Edward Gierek's visit to Rome, 17-19.10.1977, cited above.

19 Ibid.

20 "Cooperazione culturale italo-polacca", IMFA/ Directorate General for Cultural Cooperation preparatory study in view of Edward Gierek's visit to Rome, 17-19.10.1977. GA, ASILS, Polonia, Personalità A-K, Gierek, f. 572. 
between the Polish State and the Polish Catholic Church. Gierek allowed Catholics a more active role in public life and he settled old controversies, including Church claims regarding confiscated property. ${ }^{21}$ The Italian government reacted very positively to these concessions. Indeed, Rome retained that the Catholic Church's greater public role would have weakened Poland's ties with Moscow, due to the "national" and "identity value" of the Polish Kościół and its traditional role in impeding foreign assimilation policies. ${ }^{22}$

\section{Polish need for the Soviet guarantee}

Poland's growing attraction towards West Europe and the EC during the 1970's did not eradicate the Polish need for the Soviet security guarantee. Following WW II, the Polish regime considered the establishment of close relations with Moscow and, later, its entry into the Warsaw Pact, as not only due to a strained Sovietisation of the Eastern Europe but, above all, to an assessment of its practical needs. Concerning this, Wojciech Jaruzelski commented: "Considering its territory and its geo-political situation, Poland cannot be a free electron. When, following WW II, we found ourselves in a different and divided world, our place naturally was in the Warsaw Pact. I don't say now that it was for the good or for the bad, I just say it was natural". ${ }^{23}$

In Jaruzelski's reflection, it was thereby the nature itself of the European relations at the end of the war, above all the Oder-Neisse vulnerability, together with the progressive shaping of the post-war balance of power on the continent that induced the country to take its position within the Eastern bloc. Some Polish intellectuals, such as Stefan Kisielewski, shared this opinion. ${ }^{24}$ Diplomatic records indicate that Italian diplomats were well aware of the set of "historical, geographical and political factors" that were conditioning Polish foreign policy. ${ }^{25}$ The Polish border provisions in the Warsaw Treaty substantially improved the Polish perception of West Germany and, therefore, of the West European integration process, but they did not replace an international settlement or avoid the need for a Soviet guarantee.

21 "Programmi polacchi riguardo alla normalizzazione delle relazioni con la Chiesa", telegram from the Italian Ambassador to Warsaw Manlio Castronuovo, 25.11.1971. GA, ASILS, Polonia, Personalità, Wyszinksi, f. 567.

22 "Relazioni Stato-Chiesa", IMFA preparatory study in view of Edward Gierek's visit to Rome, 17-19.10.1977. GA, ASILS, Polonia, Personalità A-K, Gierek, f. 572.

23 Wojciech Jaruzelski, Interv'ju -Radiostancija Echo Moskvy, 09.5.2005 [echo.msk.ru/ guests/2606], last consulted on 07.10.2013.

24 Stefan Kisielewski, "Komu potrzebna jest Polska?”, in Tygodnik powszechny, n. 9, 1990, pp. 1-5.

25 "Politica estera polacca", IMFA preparatory study in view of Edward Gierek's visit to Rome, 17-19.10.1977. GA, ASILS, Polonia, Personalità A-K, Gierek, f. 572. 
Moreover, the Polish rush towards the West started to slow down in the late 1970 's, due to the crumbling of Poland's economy and strains within the society. Poland's foreign debts continued to rise with the deterioration of its trade balance. Being so, the Warsaw government was forced to curb its imports, therein, the EC countries suffered for the consequential fall in bilateral exchange. ${ }^{26}$ From 1976 onwards, Polish domestic production decreased and an inflationary spiral drastically slashed Poles' spending power and living standards. Moreover, Gierek's economic reform had produced a hybrid system, where elements of market and planned economy found it difficult to cohabitate, while the international monetary crisis severely reverberated within the Polish economy which was now exposed to international monetary volatility. Worker and intellectual protests then started to add social instability to this gloomy economic picture. The social effects of the economic crisis and the expectations brought about by the CSCE negotiations spawned forms of organized opposition, such as the KOR (Komitet Obrony Robotnikow). ${ }^{27}$

This domestic unraveling had a direct impact on the wavering Polish foreign policy since it harshly reminded Gierek of the limits in his international options. Indeed, in late 1977, the Farnesina noted that Polish-Soviet relations had returned to a state of "complete alignment" and this was attributed to both the economic crisis and the changing political climate within the socialist bloc following the European Communist Party Conference in East Berlin in June 1976, where the CPSU started to re-impose its authority.

According to Rome, Poland's realignment with Moscow was encouraged by the Soviet initiatives to restore socialist integration "through ideological, political and military commitments". ${ }^{28}$ In fact, around the mid 1970's the Soviet Union introduced unpopular conservative reforms into its bloc. COMECON reforms sought to tighten integration among the allied economies. In 1975, the Concerted Plan of Multilateral Integration Measures endorsed a better sharing of bloc resources as well as improved exchanges. ${ }^{29}$ The Soviet command within the Warsaw Pact was further consolidated through modifications in the Political Advisory Committee. ${ }^{30}$ Concurrently, Moscow promoted bilateral agreements as well as constitutional reforms in the East European countries that sought to reinforce inter-allied political alignment. According to the Italian diplomatic corps, these integration efforts were being bolstered by mutual

26 "Commercio italo-polacco", IMFA preparatory study in view of Edward Gierek's visit to Rome, 17-19.10.1977. GA, ASILS, Polonia, Personalità A-K, Gierek, f. 572.

27 "Polica interna polacca", IMFA preparatory study in view of Edward Gierek's visit to Rome, 17-19.10.1977. GA, ASILS, Polonia, Personalità A-K, Gierek, f. 572.

28 "Politica estera polacca", cited above.

29 Cf. William V. Wallace, Roger A. Clarke, Comecon Trade and the West, London: Frances Pinter, 1986, pp. 5-11; Joseph Pelzman, "Soviet-Comecon trade: the Question of IntraIndustry Specialization", in Review of World Economics, n. 2, vol. 114, 1978, pp. 297-304.

30 See Anatoly I.Gribkov, Sud'ba Varšavskogo Dogovora. Vospominanija, dokumenty, fakty, Moskva: Russkaja Kniga, 1998, pp. 23-36. 
visits and agreements among East European countries, including the renewal of the Polish-East German Treaty of Friendship, Cooperation and Mutual Assistance. ${ }^{31}$ A first consequence of this in Poland was the 1975 constitutional reform, which granted constitutional value to the socialist character of the state and its "indissoluble" alliance with Moscow. A second consequence was the signing of the November 1976 joint declaration where Polish alignment with Moscow was formally cited, together with a clear reference to the Brežnev Doctrine. ${ }^{32}$

Polish leadership and the society were distressed for the return to a policy of bowing to the Soviet positions, confirmed by Gierek's visit to Moscow in November 1976. The principle of bloc resource sharing was not enthusiastically accepted within the COMECON community and thereby it failed to produce economic solidarity. The 1975-1976 political reforms immediately provoked protests among intellectual and Catholic circles, which coupled with riots in Ursus and Radom instigated by rising staple prices. ${ }^{33}$

In face of this, the Warsaw government tried to make up for the tightening of its Eastern ties by maintaining diplomatic contacts with West European countries. In fact, the normalisation of Polish relations with West Germany was not interrupted, but it was further enhanced by Gierek's visit to Bonn, in July 1976, and Chancellor Schmidt's visit to Warsaw, in December 1977. The same can be said for Polish relations with other West European countries, such as the 1977 visits by Gierek to Paris and Rome. ${ }^{34}$

Even if the Polish international stance during the 1970's remained strongly anchored to the Soviet concept of European security, according to the Italian analysis the Polish government appeared to be open to different alternatives. Unlike the Russian perspective, "the Polish vision" was considered "non-static". ${ }^{35}$ The Warsaw government was persuaded that the Helsinki Final Act was the grounds for "a peaceful evolution of European cooperation over the next decades". ${ }^{36}$ and it demonstrated this conviction by exercising a more flexible stance at the 1977 Belgrade Conference, where the Polish delegation adopted a proactive approach, far less polemic than the Soviets' and other satellites'. ${ }^{37}$ According to Rome, this

31 Other examples include Ceaușescu's 1977 visit to Warsaw and his signing of the PolishRomanian joint declaration, Gierek's 1977 visits to Prague and Budapest, and Prime Minister Jaroszewicz's visit to Sofia in October 1977.

32 "Politica estera polacca", cited above.

33 "Politica interna polacca", cited above.

34 "Politica estera polacca", cited above.

35 "CSCE: posizione polacca", IMFA preparatory study in view of Edward Gierek's visit to Rome, 17-19.10.1977. GA, ASILS, Polonia, Personalità A-K, Gierek, f. 572.

36 Cf. Wanda Jarząbek, "Preserving the status quo or promoting change: the role of the CSCE in the perception of Polish authorities", in Helsinki 1975 and the Transformation of Europe, cited above, pp. 144-159.

37 "CSCE: posizione polacca", cited above. 
suggested that there was a constant quest for a reliable European security system behind the Polish wavering.

\section{East or West: a challenging choice for Poland}

From the end of the 1970's, the failure of Polish Market Socialism became undeniable and brought about a full rejection of Gierek's half-reformed system. This fueled both the ongoing domestic confrontation between the state and the society as well as the Soviet pressures for a quick repression of mounting political opposition. Solidarity leaders demanded radical reforms which, according to the Italian Ambassador to Warsaw Marco Favale, would have not been tolerated by the Soviet Union due to its fear of a Polish "Westernisation" process, even in the form of a "third way". ${ }^{38}$ Acceleration in domestic liberalisation would have therefore pushed Warsaw to a breaking point with Moscow. Therefore, the introduction of Martial Law halted a domestic evolution that the Polish government feared it could not control.

To this regard, in 1982, Ambassador Favale reminded Rome of the natural limits of Polish autonomy from Moscow. In fact, both Warsaw and Moscow still shared the persuasion that the Helsinki principle of boundary inviolability, the Ostverträge and the Quad's agreements represented a whole: according to the old Latin dictum "simul stabent, simul cadent", they all would have been respected or none of them would have been. ${ }^{39}$ This meant that Warsaw was as persuaded as Moscow that East-West coexistence and cooperation in Europe had to be based upon the West's acceptance of Eastern regimes and, especially, the East German regime.

In the early 1980's Poland was still caught between change and restoration which led to a choppy Polish foreign policy during the 1980-81 crisis. The country strove to restore political and economic support from the Soviet Union and the other socialist countries without permanently jeopardizing its Western relations. In fact, the Polish government was avoiding making a radical choice regarding the orientation of its foreign relations. The resulting behaviour was a Polish wavering between a policy of reassurance towards its Eastern allies, regarding its unbroken loyalty towards both the Warsaw Pact and socialist ideals, and a quest to justify to West European governments the hard choices it had been forced to take by introducing Martial Law.

According to the Italian government, what the Poles were truly seeking was a "historical normalisation" of their foreign relations, not only an "economic and "psychological" one, with a central focus on the traditional claim regarding the

38 Note from the Italian Ambassador to Warsaw Marco Favale (without date, attributable to 1982). GA, ASILS, Polonia, Viaggi 1981 and 1984, f. 569.

39 Note from the Italian Ambassador to Warsaw Marco Favale (without date, about May 1982). GA, ASILS, Polonia, Ambasciata, f. 567. 
international acknowledgement of the Oder-Neisse border. ${ }^{40}$ The Polish leadership was therefore described as "chased by the ghosts of its history and torn between the Western and the Eastern calls". ${ }^{41}$

The normalization of Polish Eastern relations remained a top priority for the country until the mid 1980's since the Soviet bloc still was its first security reference. Jaruzelski's visits to allied countries between 1982 and 1984 helped to restore a positive inter-allied climate, with the only exception of EastGermany. Above all, Polish-Soviet relations were developing in a very satisfactory manner, following Brežnev's initial suspicions concerning the ambiguities of Jaruzelski's Martial Law. ${ }^{42}$ The improvement in bilateral relations brought about a renewed political endorsement, as well as substantial financial aid from Moscow, both of which favoured a certain expansion of Polish trade in the COMECON area. $^{43}$

Regarding the West, the normalisation of Polish relations with Western Europe remained an urgent issue. Uncertainties regarding the continuity of Western credit flows and the US economic sanctions, triggered by the Solidarity crisis, led to a sudden and severe economic downturn in Poland, due to the highly developed interdependence among the European economies. Nonetheless, this did not mean that the Polish dependence on West European credits could have induced the country to shirk on its Eastern commitments. Indeed, the need for Western support was counterbalanced by military concerns following the deployment of the intermediate nuclear missiles in West Germany and the reopening of a thorny debate on the future of the German military status.

Whenever there were no desirable options, the Polish government simply refrained from choosing. In mid 1980's, Jaruzelski strongly reasserted Poland's commitment to the European project, while at the same time advocating a true "Europeanisation" of the continent. This would have required not just a West European willingness to cooperate with the socialist countries, but also the political acceptance of the socialist governments. ${ }^{44}$ One can also add that this Europeanised Europe, and the acceptance of the existence of a Socialist Germany which it entailed, would have satisfactorily met the Polish security demands. Nonetheless, the sacrifice of the German aspiration to live in a reunified nation was too high a price to ask to bring back Poland into Europe. Therefore, the key to the problem

40 "Politica estera polacca", cited above.

41 Ibid.

42 Brežnev's reacted with initial distrust to Jaruzelski's decision to introduce Martial Law as demonstrated in the CPSU bulletin "Ob oficial'nom vizite partijno-gosudarstvennoj delegacii PNR vo glave s V. Jaruzel'skim v Moskvu 1-2 marta 1982”, 07.03.82, Sovetskij Archiv [bukovsky-archives.net/pdfs/poland/pol-gdr82.pdf],last consulted on 07.10.2013.

43 "Politica estera polacca", cited above.

44 Ibid. 
had to be found in a strengthened European interdependence and in a renewed security system. ${ }^{45}$

\section{The crisis of détente and the 1984 Andreotti visit to Poland}

During the Détente Crisis, Polish domestic tensions were amplified by international concerns generated by the 1979 NATO double-track decision. The looming theatre nuclear missile deployment in West Germany re-instilled old angst in Poland. Moreover, this military development was coupled with an ongoing political upheaval in Bonn, following the 1982 election of Helmut Kohl's centre-right government. The incoming Federal Chancellor reassured Poland that German Ostpolitik would not change under the new government. Nevertheless, the Poles remained suspicious, as demonstrated by the cancelation of the 1984 visit by Foreign Minister Hans-Dietrich Genscher to Warsaw.

Hans-Jochen Voegel, the SPD opposition leader, told Luigi Vittorio Ferraris, the Italian Ambassador to Bonn, that the deterioration of Polish-West German relations was due to both bilateral and wider international circumstances. On one hand, the new CDU leadership had gained its electoral consent on the promises of both renewed West-German-American cooperation, which included the INF deployment, and greater attention to German revisionist circles. On the other hand, Voegel was persuaded that the hurdles that the CDU was encountering could also be seen as a consequence of the lingering strains in bipolar relations as well as a growing instability within the Eastern bloc. ${ }^{46}$

Polish relations with the West, and especially with Washington, temporarily experienced a setback due to Martial Law and the Polish security dilemma. Thereby, a reorientation of Polish political and economic ties towards the Soviet Union became greatly feared, especially by the West German and Italian governments who agreed upon conciliatory gestures having the aim of resuming a confidence-building process. Bonn's diplomatic difficulties, emotionally amplified on the eve of the $40^{\text {th }}$ anniversary of the end of WW II, could have been eased by mediating initiatives on the part of Italy and Western allies. The ongoing renewal of diplomatic contacts between Rome and Warsaw, therefore, along with the planned visit by Honecker to Rome, could have supported the Eastern leaders, including Jaruzelski, in those critical circumstances, by widening their

45 On the concept of "interdependence" cf. Federico Romero, Antonio Varsori (eds.), Nazione, interdipendenza, integrazione. Le relazioni internazionali dell'Italia, 1917-1989, Roma: Carocci, 2006; Ennio Di Nolfo, "La politica estera italiana tra interdipendenza e integrazione", in Agostino Giovagnoli, Silvio Pons, Tra guerra fredda e distensione, Soveria Mannelli: Rubbettino, 2003, pp. 17-28.

46 "Relazioni con la Polonia e la RDT: conversazioni con il presidente del gruppo parlamentare SPD Voegel", telegram by the Italian Ambassador to Bonn Luigi Vittorio Ferraris, 12.12.1984. GA, ASILS, Polonia, Viaggi, f. 571. 
manoeuvring room vis à vis the Soviet Union as well as encouraging a more flexible approachto security issues. ${ }^{47}$

Following the Solidarity crisis, Italian-Polish relations were described by the Farnesina's General Secretariat as "an exception", compared with FrenchPolish and West German-Polish relations, since they were characterised by lack of controversies and greater confidence. ${ }^{48}$ Indeed, Italy was perceived as a less menacing partner than Bonn and the Euromissiles deployed on Italian soil did not arouse the same Polish concerns as those deployed on German soil. Also, Italy's foreign policy was considered by the Poles to be more reassuring than those of other EC countries. Specifically, unlike Mitterrand's and Kohl's electoral successes, the 1983 election of the socialist government led by Bettino Craxi gave the idea of continuity with the Christian Democrat Ostpolitik, especially due to the appointment of Andreotti as Foreign Minister. ${ }^{49}$ Moreover, diplomatic contacts with Rome would have led to better contacts with the Vatican, whose international stances had become extremely influential in Polish domestic affairs.

From January 1982, the Polish government sought to open a diplomatic channel through its embassy in Rome, by inviting Andreotti to Poland in that March, together with three other Christian Democrat deputies. ${ }^{50}$ To this, Andreotti responded "we will see", demonstrating both his openness and his prudence to the offer..$^{51}$ In fact, it was not until December 1984 that Foreign Minister Andreotti made this visit, following the enactment of the first Polish amnesty. Before the visit, Italian diplomats had highlighted domestic and international reasons why the time had come for an official visit: the ongoing relaxation of Polish state-society relations and the Western concerns regarding a possible radicalisation of the Polish policy of reorientation towards the East. ${ }^{52}$

\section{Ibid.}

48 "Polonia", IMFA/Secretariat General report, June 1985. GA ASILS, Europa, Consiglio Europeo di Milano, June 28-29, 1985, f. 377. Due to French public sentiment, at the beginning of the 1980's Mitterrand decided to keep his relations with the Warsaw government at a low profile. Proof of this was the late and low key visit by General Jaruzelski to Paris on 4th December 1985, which was the first bilateral summit following the introduction of martial law.

49 See Ennio Di Nolfo (ed.), La Politica estera italiana negli anni '80, Venezia: Marsilio, 2007, and specifically par. "L'Italia e la Ostpolitik", with contributions by Giorgio Petracchi, Luigi V. Ferraris, Roman Gutkowski, pp. 271-324.

50 Memorandum to Giulio Andreotti, January 1982. GA, ASILS, Polonia, Viaggi 1981 and 1984, f. 569.

51 President of the Parliamentary Commission for Foreign Affairs Giulio Andreotti to the Italian Ambassador to Warsaw Marco Favale, Rome, 18.5.1982. GA, ASILS, Polonia, Viaggi 1981 and 1984, f. 569.

52 "Polonia-situazione interna", IMFA preparatory study in view of Giulio Andreotti visit to Warsaw, 20-22.12.1984. GA, ASILS, Polonia, Viaggi, f. 571. 
This visit had the aim of persuading the Poles that both the evolution of the European strategic scenario would have been risk-free and the European Union would have held great prospects for European security and cooperation. At the summit, Jaruzelski opened the talks reiterating that Poland's close rapprochement to the Soviets was a "historical and contemporary free choice" while refusing the idea that it was a subordinate relationship..$^{53}$ At the say time, anyway, he expressed his will to preserve, as much as possible, the Polish "specificity" and, specifically, Polish economic reforms. However, he also confessed that maintaining such a system had become very onerous. ${ }^{54}$ The Western countries, especially the US sanctions, were jeopardizing the fruits of a decade of economic cooperation, thus forcing Poland to renounce half of its imports which led to serious economic damages. Being so, Jaruzelski concluded that the economic reorientation towards the Soviet Union was not an ideological or emotional choice, but would have been dictated by national interests:"In our opinion, the line to follow is dictated by what the country needs [...]. The iron curtain is historically outdated. Nonetheless, I believe that the reasons for which we need to be cautious in rebuilding our relations with the West are understandable". ${ }^{5}$

These "understandable" reasons obviously includedPoland's "known" security concerns, as the Polish Foreign Minister Stefan Olszowski missed no opportunity to reassert during the meeting. Olszowski said that the Poles were interested in avoiding any new military threat that could arise from Germany and were afraid of the revisionist and revanchist manifestations, specifically of "some declarations which leave open the German problem and question the intangibility of the European boundaries". Moreover, he added that this Polish fear was sharpened by the aggressive behaviour on the part of the US. ${ }^{56}$

Andreotti sought to dissipate these security fears by persuading the Polish Minister that the continental strategic situation would have soon evolved into a new military balance and the Stockholm Conference on Disarmament in Europe (CDE) would have successfully elaborated a concrete platform on arms reduction. He was also confident that the Geneva negotiations between the superpowers would have resumed in 1985, on the wave of intensified contacts between NATO and the Warsaw Pact. Andreotti believed that by visiting Warsaw, he was further encouraging the resumption of the East-West dialogue.

But, as important as the bipolar agreements might have been, according to Andreotti, the task of reforming the inter-European relations lay properly on the

53 Telegram from the General Director of Foreign Affairs, Bruno Bottai, 22.12.1984. GA, ASILS, Polonia, Viaggi 1981 and 1984, f. 569.

54 Ibid.

55 Minutes of talks between Giulio Andreotti and Wojciek Jaruzelski, 22.12.1984, part I. GA, ASILS, Polonia, Viaggi 1981 and 1984, f. 569.

56 Minutes of talks between Giulio Andreotti and Stefan Olszowski, 20.12.1984, GA, ASILS, Polonia, Viaggi 1981 and 1984, f. 569. 
shoulders of European countries: "We are responsible, also bilaterally, for building a new type of relations, where there is total respect for the independence and intangibility of the boundaries of each and every nation, parallel to a shared quest for an active collaboration and forms of economic solidarity". ${ }^{57}$

Andreotti shared the Polish aspirations of garnering the West European solidarity, as well as having safe borders, but he did not recognise the socialist regimes as being unchangeable and unreformable entities. The Helsinki process was turning out to be a path for the rebuilding of the inter-European relations, in which all countries had a role to play while respecting their alliances, but with the ultimate goal of reaching similar stances. The EC facilitated this process through three main goals: 1) engage European countries in the peaceful destruction of the continental armaments; 2) avoid that any new conflict could arise between France and Germany; 3) combine the economies of the European countries in order to strengthen their collective stance.

Olszowski completely agreed with Andreotti that the superpowers needed to be the frame of the picture but it had to be the medium-sized countries within Europe who realised it. Albeit, Olszowski remained skeptical regarding Andreotti's confidence in what he believed would have been a quick improvement in bipolar negotiations. Also, the Polish Minister exhibited certain helplessness when he remarked: "What can we do in Warsaw? We do not have many original ideas. We run in circles around a certain reality deriving from international relations". 58

Here, once again, Andreotti reassured Olszowski on what he believed were the positive prospects emerging at the Stockholm Conference: the joint declaration on non-use of force, that the Soviet Union and the Eastern countries demanded, should be the framework for practical and well-defined Confidence Building Measures. The Soviets had already facilitated this process by accepting to divide nuclear and conventional problems, that is, separately negotiating to renounce the first use of nuclear arms and renounce the use of force.

\section{Towards a new concept of inter-European relations}

The productive climate of Andreotti's talks in Warsaw was revived by the visit that Prime Minister Craxi made to Warsaw in May 1985. These summits aimed to restore the East-West European dialogue on security and cooperation which, according to the Italian government, had become urgent in the mid 1980's due to the swift resumption of bipolar dialogue. Following the worst years of the Détente crisis, President Reagan softened his Soviet policy, which included both pursuing more pragmatic bipolar relations and achieving concrete agreements. The Soviet Union, on the other hand, following Brežnev's passing, showed growing interest 
in these US steps which led to Andropov's gambit regarding the INF issue. This more flexible stance was attributed to Soviet collegial and less united direction, as well as bloc instability and technological and economic gaps.

At the end of 1984, the Italian government noted that both the superpowers seemed to be more inclined to reach an agreement on their European differences, by circumscribing the free initiatives of their minor allies. For this, the Italian government was concerned about a "return to a bipolar scheme" of negotiations which would have limited the European role in the security and disarmament talks. To avoid this, as in Helsinki in 1972, Eastern and Western European countries needed to be collectively engaged in order to exert a greater leverage on the superpowers and obtain an active role in the disarmament process. Some Eastern leaders had already independently revitalized their Westpolitik hoping to renew the panEuropean dialogue on security matters. Specifically, the 1984 visits of Kádár to Paris and Ceaușescu to Bonn openly challenged the Soviet opposition. Moreover, in early 1984, the socialist countries had endorsed new joint political documents, such as the April Budapest declaration and the June declaration of the COMECON Political Committee, demanding the renewal of a "policy of dialogue and negotiation with the West based upon realism and concrete collaboration". ${ }^{59}$ These joint initiatives encouraged a more flexible Soviet approach to security and strategic issues and promoted a greater commitment on the part of Moscow to achieve shared goals at the Stockholm CDE Conference. ${ }^{60}$

The efforts of the European countries were rewarded in December 1984, when the CDE negotiations were able to begin, following an agreement on the procedural mechanisms which had, for long time, stalled the opening of the conference. Nonetheless, the positions of participating countries remained far apart: Western countries demanded the introduction of affective CBMs; neutrals requested a drastic reduction in military activity; whereas, Warsaw Pact sought a collective declaration on the non-use of force. The Italian government foresaw a final compromise based on a convergence of these stances. ${ }^{61}$ Through the CDE talks, the European countries would have introduced innovative East-West CBMs, including on-site inspections on demand, as well as pursued an effective reduction of conventional arms. ${ }^{62}$ The Stockholm confidence-building process, therefore, had

59 "Relazioni Est-Ovest", IMFA preparatory study in view of Giulio Andreotti visit to Warsaw, 20-22.12.1984. GA, ASILS, Polonia, Viaggi, f. 571.

60 On the concept of cooperative security cf. James Goodby,Europe undivided, Washington: USIP, 1998, and The Stockholm conference: negotiating a cooperative security system for Europe, Washington: Foreign Service Institute, Occasional Paper n. 6, 1987.

61 "CDE: stato dei negoziati alla Conferenza di Stoccolma dopo la 4a sessione, 14.12.1984", IMFA preparatory study in view of Giulio Andreotti visit to Warsaw, 20-22.12.1984. GA, ASILS, Polonia, Viaggi, f. 571.

62 On this subject cf. John Freeman, Security and CSCE process: the Stockholm Conference and beyond, London: Pelgrave McMillan, 1991; Carl C. Krehbiel, Confidence- and Security 
to provide practical responses to the unresolved post-war differences in Europe, including Polish security concerns. Thus, the Italian government considered the restoration of Poland's active role in this process more important than ever: "It is therefore an evident Western interest to promote as well as respond to these pushes toward East-West dialogue. The gradual reinsertion of Poland into a normalized circuit of political contacts and cooperation with the West European countries continued to respond to this interest, in spite of the difficulties in this process made evident by the recent postponement of Genscher's visit to Warsaw". ${ }^{63}$

Andreotti also insisted that the Poles be more confident in the European Union project, which he considered the only possible solution to the German problem: "if the European Union is realized, the historical danger of an expansionist Germany will be removed". ${ }^{64}$ In fact, the EU envisioned strong links of economic interdependence and military confidence among the European countries, thereby avoiding national conflicts and peacefully including a reunified Germany. Jaruzelski responded to Andreotti's pro-European pronouncements with some overtures. Indeed, he assured the Italian Foreign Minister that Poland would have played a very active role in Stockholm. Moreover, Jaruzelski believed that the appointment of Marshal Sergej Sokolov as Defense Minister would have further softened the Soviet strategic stance. ${ }^{65}$

The Italian-Polish summits were followed by a substantial improvement in Poland's political relations with the EC countries, also due to the parallel resumption of economic relations among them. In 1983, the Italian-Polish trade exchange recorded a significant increase, with a $40 \%$ growth in Italian imports. However, financial support from West Europe did not pick up as fast, given the huge Polish arrears in debt payments. In fact, Warsaw was not able to honour its European debts between 1982 and 1984, with the debt towards Italy reaching $\$ 1.185$ billion, of which \$ 600 million was overdue. Being so, the Italian government was very hesitant to grant ulterior credits to Poland, therein, the initial resumption of bilateral exchanges was sustained by Italian industries that resorted to international credit at their risk. ${ }^{66}$

This recovery in bilateral trade initially developed out of the institutional framework and soon regained the support of the Italian-Polish Joint Commission, which

building measures in Europe: the Stockholm Conference, New York: Praeger 1989; John Borawski, From the Atlantic to the Urals: negotiating arms control at the Stockholm Conference, London: McMillan, 1987.

63 "Relazioni Est-Ovest", cited above.

64 Minutes of talks between Giulio Andreotti and Wojciek Jaruzelski, 22.12.1984, part II. GA, ASILS, Polonia, Viaggi 1981 and 1984, f. 569.

65 Ibid.

66 "Relazioni economiche italo-polacche, 12.12.1984", IMFA/ Directorate General for Economic Affairs preparatory study in view of Giulio Andreotti visit to Warsaw, 20-22.12.1984. GA, ASILS, Polonia, Viaggi, f. 571. 
resumed talks in Rome at the beginning of October 1984. To this regard, during Andreotti's visit to Warsaw, a new agreement on economic cooperation was signed which updated the 1975 arrangements. The Italian Foreign Minister also exerted strong pressure on the Italian Minister of Treasury GiovanniGoria to overcome the obstacles in providing new credits. ${ }^{67}$ In 1986, a bilateral agreement on the rescheduling of the outstanding debts was reached and the SACE agency decided to insure the transactions with payment delays for up to 12 months. ${ }^{68}$ This reawakening in Italian-Polish economic relations also took place between Poland and other EC countries, thanks to the Paris Club agreement on the Polish debt rescheduling which led to a noteworthy recovery in bilateral exchanges over the 1984-1985 period, following the bottoming out in 1981-1982. ${ }^{69}$ Therein, Poland was once again strongly attracted to the EC market.

\section{Conclusions}

In the second half of the 1980's the Polish reorientation towards the Soviet bloc was averted. Brežnev's plans to restore a firm Soviet control on a strongly integrated alliance had failed and this fostered new currents of thought among Soviet foreign policy makers, allowing Gorbačev and his new thinking to prevail.

Muddling through the bloc system, Europe was gradually moving away from the post-war order. Nonetheless, Polish uncertainties remained deeply rooted. ${ }^{70}$ From the mid 1980's, Gorbačev had promoted inter-allied reforms granting more political freedom to the socialist countries, thus loosening the intra-bloc relations and weakening the military guarantee of the Warsaw Pact. ${ }^{71}$ These reforms also led to a weaker backing of the East German regime, with unpredictable consequences in inner-German relations. Meanwhile, Gorbačev's proposal to build a Common European Home, with German-Soviet relations as the corner-stone, aroused in Poland old fears of a new Rapallo agreement.

Ambassador Ferraris communicated to Rome in late 1985 that the Bonn government was aware that any further rapprochement to Pankow or Moscow would have been unwelcomed in Warsaw. Albeit, Bonn could not realistically renounce

67 Foreign Minister Giulio Andreotti to the Minister of Treasury Giovanni Goria, Rome, 18.12.1984. GA, ASILS, Polonia, Viaggi, f. 571.

68 "Relazioni economiche bilaterali", FMA preparatory study in view of General Jaruzelski's visit to Rome, 7.11.1987, Rome. GA, ASILS, Polonia, Personalità A-K, Jaruzelski, f. 572.

69 Ibid.

70 See Robert Cooper “Integration and Disintegration”, in Journal of Democracy, n. 1, vol. 10, 1999, pp. 8-21.

71 Cf. The Diary of Anatoly Chernyaev, entries for January 4 and March 30, 1985 (ed. by Svetlana Savranskaja), [www2.gwu.edu/ nsarchiv/NSAEBB/NSAEBB192/Chernyaev_ Diary_translation_1985.pdf], last consulted on 07.10.2013, and Anatolij S. Černjaev, My Six Years with Gorbachev, University Park: Pennsylvania State University Press, 2000, p. 12. 
its inner-German relations along with its renewed relations with the Soviet Union. ${ }^{72}$ In March 1985, Genscher dropped in on Warsaw and in September 1985 a meeting took place between Jaruzelski and Genscher alongside a UN Assembly reunion. Ambassador Ferraris held that the meetings had not produced any serious rapprochement on strategic issues, due to the recurrent Polish proposal to create a nuclear as well as chemical arm free zone in Central Europe. According to Ambassador Ferraris, the Poles still feared that a reunified Germany would not have recognized the commitments on the Oder-Neisse taken by the West German government.

Nonetheless, Poland was gradually starting to make overtures, including the approval of an official visit by Genscher to Warsaw. ${ }^{73}$ The Italian government considered both Olszowski's withdrawal from the PUWP electoral list as a signal of change and the Brussels Declaration, endorsed by the Atlantic Alliance in December 1986, as the Western response to the 1984 Budapest Declaration. In fact, the Brussels declaration proposed opening immediate talks, aside and distinct from the MBFR, in order to reach a conventional arms balance at the lowest possible level from the Atlantic to the Urals. During Jaruzelski's visit to Rome, in January 1987, the Italian government repeatedly stressed the significance of such negotiations which had the aim of promoting "a major conventional stability through a balance of power with reduced offensive capacity". ${ }^{74}$ In the Italian opinion, this conventional disarmament was to be pursued before nuclear disarmament, given that, during this process, the bipolar nuclear armaments would have remained an indispensable 'umbrella' for Europe. Indeed, a conventional balance would have curbed the European reliance on nuclear armaments and strengthened both the inter-European confidence and security ties.

The decline of Gorbačev's Common European Home at the beginning of the 1990's quelled the remaining Polish fears of a dominant German-Russian axis. A further assurance came in the form of Poland's entry into NATO. Concurrently, Poland's attraction towards the EC and the promising Single Market continued to grow and Polish economic recovery relied ever more unilaterally on the West. Exploratory talks between the EC and Warsaw initiated in July 1986, with the aim of establishing a trade agreement as well as diplomatic relations between the two. West Germany remained the biggest trade partner for Poland, bringing about an even greater interdependence. ${ }^{75}$ The 1986 Vienna agreement, which outlined

72 Telegram by the Italian Ambassador to Bonn Luigi Vittorio Ferraris, 3.10.1985. GA, ASILS, Polonia, Rapporti con la Germania, f. 574.

73 Ibid.

74 "Visita ufficiale in Italia del Presidente del Consiglio di Stato e Primo Segretario del POUP, Generale Wojciech Jaruzelski (12-14.12.1987). Problemi del disarmo convenzionale", IMFA preparatory study in view of General Jaruzelski's visit to Rome, 7.11.1987. GA, ASILS, Polonia, Personalità A-K, Jaruzelski, f. 572.

75 "EC-Polonia", IMFA preparatory study in view of General Jaruzelski's visit to Rome, 7.11.1987. GA, ASILS, Polonia, Personalità A-K, Jaruzelski, f. 572. 
an ulterior rescheduling of the Polish debt, as well as Poland's accession to the IMF, in May 1986, both greatly contributed to the Polish rapprochement with West European countries. ${ }^{76}$

The renewal of Polish trust in Europe, coupled with the successful conclusion of the Round Table process, represented fundamental advances for building the European Union and promoting its Eastern enlargement. As Andreotti had predicted in Warsaw, the interdependence among the European economies was becoming the new guarantee of cooperation and peaceful coexistence among the European countries.

\section{Bibliography}

Bange, Oliver, Niedhart, Gottfried (eds.), (2008), Helsinki 1975 and the transformation of Europe, Oxford-New York: Berghahn Books.

Bange, Oliver, (2008), "An intricate web: Ostpolitik, the European security system and German Unification", in Bange, Oliver, Niedhart, Gottfried (eds.), Helsinki 1975 and the transformation of Europe, Oxford-New York: Berghahn Books, 43-64.

Borawski, John, (1987), From the Atlantic to the Urals: negotiating arms control at the Stockholm Conference, London: McMillan.

Brandt, Willy, (1991), Memorie [Erinnerungen], Milano: Garzanti.

(von) Dannenberg, Julia, (2008), The Foundations of Ostpolitik: The Making of the Moscow Treaty Between West Germany and the USSR, London-New York: Oxford University Press.

Černjaev, Anatolij S., (2000), My Six Years with Gorbachev, University Park: Pennsylvania State University Press.

COMECON DATA 1979, (1980), London: Vienna Institute for Comparative Economic Studies. Cooper, Robert, (1999), "Integration and Disintegration”, inJournal of Democracy, n. 1, vol. 10, 8-21.

Craveri, Piero, Varsori, Antonio (eds.), (2009), L'Italia nella costruzione europea. Un bilancio storico (1957-2007), Milano: Franco Angeli.

Di Nolfo, Ennio (ed.), (2007), La Politica estera italiana negli anni '80, Venezia: Marsilio.

Di Nolfo, Ennio, (2003), "La politica estera italiana tra interdipendenza e integrazione", in Giovagnoli, Agostino, Pons, Silvio, Tra guerra fredda e distensione, Soveria Mannelli: Rubbettino, 17-28.

Fink, Carole, Schaefer, Bernd (eds.), (2009), Ostpolitik, 1969-1974: European and global responses, Cambridge: Cambridge University Press.

Freeman, John, (1991), Security and CSCE process: the Stockholm Conference and beyond, London: Pelgrave McMillan.

Giovagnoli, Agostino, Pons, Silvio, (2003), Tra guerra fredda e distensione, Soveria Mannelli: Rubbettino.

Goodby, James, (1998), Europe Undivided, Washington: United States Institute of Peace Press. Goodby, James, (1987), The Stockholm Conference: negotiating a cooperative security system for Europe, Washington: Foreign Service Institute, Center for Study of Foreign Affairs, Occasional Paper n. 6.

76 "Debito estero polacco", IMFA preparatory study in view of General Jaruzelski's visit to Rome, 7.11.1987. GA, ASILS, Polonia, Personalità A-K, Jaruzelski, f. 572. 
Gribkov, Anatoly I., (1998), Sud'ba Varšavskogo Dogovora. Vospominanija, dokumenty, fakty, Moskva: Russkaja Kniga.

Haftendorn, Helga, (2006), Coming of Age: German Foreign Policy since 1945, Lanham: Rowman \& Littlefield.

Hofmann, Arne, (2007), The Emergence of Détente in Europe. Brandt, Kennedy and the Formation of Ostpolitik, London-New York: Routledge.

Jaruzelski, Wojciech, (09.5.2005), Interv'ju - Radiostancija “Echo Moskvy” [echo.msk.ru/ guests/2606], last consulted on 07.10.2013.

Jarząbek, Wanda, (2010), "Polish reactions to the West German Ostpolitik and East-West détente, 1966-1978", in Villaume, Poul, Westad, Odd A. (eds.), Perforating the iron curtain: European détente, transatlantic relations, and the Cold War, 1965-1985, Copenhagen: Museum Tusculanum Press, 35-56.

Jarząbek, Wanda, (2008), "Preserving the status quo or promoting change: the role of the CSCE in the perception of Polish authorities", in Bange, Oliver, Niedhart, Gottfried (eds.), Helsinki 1975 and the transformation of Europe, Oxford-New York: Berghahn Books, 144-159.

Kisielewski, Stefan, (1990), “Komu potrzebna jest Polska?”, in Tygodnik powszechny, n. 9, 1-5.

Krehbiel, Carl C., (1989), Confidence-and Security building measures in Europe: the Stockholm Conference, New York: Praeger.

Loth, Wilfried, Soutou, George-H. (eds.), (2008), The Making of Détente: Eastern and Western Europe in the Cold War, 1965-75, London-New York: Routledge.

Ludlow, Piers N. (ed.), (2007), European Integration and the Cold War: Ostpolitik-Westpolitik, 1965-1973, London: Routledge.

Möckli, Daniel, (2009), European Foreign Policy during the Cold War, London: I. B. Tauris.

Nuti, Domenico M., (1981), "The Polish crisis: economic factors and constraints", in Socialist Register, vol. 18 [socialistregister.com/index.php/srv/article/view/5463], last consulted on 07.10.2013.

Pelzman, Joseph, (1978), "Soviet-Comecon trade: the Question of Intra-industry Specialization", in Review of World Economics, n. 2, vol. 114, 297-304.

Posadnev, Jurij V., (1983), Problema zapadnoj granicy PNR v Bundestage FRG v 1969-1972 g, Moskva: Ministerstvo Prosveščenija RSFSR.

Romano, Angela, (2010), "The main task of European Political Cooperation: fostering détente in Europe", in Villaume, Poul, Westad, Odd A. (eds.), Perforating the iron curtain: European détente, transatlantic relations, and the Cold War, 1965-1985, Copenhagen: Museum Tusculanum Press, pp 123-142.

Romero, Federico, Varsori, Antonio (eds.), (2006), Nazione, interdipendenza, integrazione. Le relazioni internazionali dell'Italia, 1917-1989, vol. 1 and 2, Roma: Carocci.

Ruchniewicz, Krzysztof, (2009), "Ostpolitik and Poland”, in Fink, Carole, Schaefer, Bernd (eds.), Ostpolitik, 1969-1974: European and global responses, Cambridge: Cambridge University Press, 39-57.

Savranskaja, Svetlana (ed.), The Diary of Anatoly Chernyaev: 1985 [www2.gwu.edu/ nsarchiv/ NSAEBB/NSAEBB192/Chernyaev_Diary_translation_1985.pdf], last consulted on 07.10.2013.

Sokoloff, Georges, (1987), The economy of Détente. The Soviet Union and Western Capital, Hamburg, New York, Berg Publisher-Leamington Spa.

Tosi, Luciano (ed.), (2008), L'Italia e la dimensione sociale nell'integrazione europea, Padova: Cedam.

Van Ham, Peter, (1995), The EC, Eastern Europe and European Unity. Discord, Collaboration and Integration Since 1947, London-New York: Pinter. 
Van Oudenaren, John, (1991), Détente in Europe. The Soviet Union and the West since 1953, Duhram: Duke University Press.

Varsori, Antonio, (2013), L'Italia e la fine della guerra fredda: La politica estera dei governi Andreotti (1989-1992), Bologna: Il Mulino.

Varsori, Antonio, (2010), La Cenerentola d'Europa. L'Italia e l'integrazione europea dal 1947 ad oggi, Soveria Mannelli: Rubbettino.

Villaume, Poul, Westad, Odd A. (eds.), (2010), Perforating the iron curtain: European détente, transatlantic relations, and the Cold War, 1965-1985, Copenhagen: Museum Tusculanum Press.

Wallace, William V., Clarke, Roger A., (1986), Comecon Trade and the West, London: Frances Pinter.

Weber, Pierre-Frédéric, (2007), Le Triangle RFA-RDA-Pologne (1961-1975). Guerre froide et normalisation des rapports germano-polonais, Paris: L'Harmattan.

Zagorskij, Andrej V., (2005), Chel'sinkskij process, Moskva: Prava Čeloveka.

Zoltán, Marusza, (2008), "Denuclearization in Central Europe? The Rapacki Plan during the Cold War" [coldwar.hu/html/en/publications/Online\%20PublicationMar.pdf], last consulted on 07.10.2013.

Archival sources:

Giulio Andreotti Archive (GA), Historical Archive of the Luigi Sturzo Institute (ASILS), Rome.

- Polonia: Ambasciata (567); Viaggi 1981 e 1984 (569); Viaggi (571); Personalità A-K (572); Personalità K-Z (573); Rapporti con la Germania (574).

- Europa: Consiglio Europeo di Milano (377).

Sovetskij Archiv (collected by Vladimir Bukovskij) [bukovsky-archives.net], last consulted on 17.10.2013. Poland.

Declassified Documents Reference System (DDRS). Primary Source Media, Thomson Gale. The Declassified Documents. Vol. 1992. 